\title{
Alternative Conceptions of Modernity in the History of Iban Popular Music
}

\section{Connie Lim Keh Nie}

PhD candidate, Music Department, Faculty of Human Ecology, Universiti Putra Malaysia Email: climkn@gmail.com; lknconnie@unimas.my

\begin{abstract}
This paper examines how modernity has historically shaped developments in the industry of Iban popular music. The Iban make up one third of the Sarawakian population and are the largest indigenous ethnic group in Sarawak, Malaysia. As with other ethnicities in the nationstate, modernity has presented challenges for socio-cultural development and lifestyle of Iban people. Historically, the Iban are a cultural group located geographically and politically on the periphery of the multi-cultural nation of Malaysia. Throughout much of the 20th century, the music industry has experienced a rapid embrace of modernity through the nation to the detriment of traditional practices in culture in order to adapt themselves in the era of modernization. Iban society had gone through a state of flux where people have gone through the process of readapting themselves in meeting the demanding challenges of Malaysian nationalism. Drawing upon Barendregt's (2014) 'alternative conceptions of modernity' this paper examines how the Iban reference both a national as well as a local music industry particularly through their use of language as an expression of Iban. First the paper will examine changes in Iban society through political and economic modernization. Then I look at differential transformation within Iban music industry because of relative exposure to agents of change such as the influence through Christian missionary and education. This reflects how the Iban react and reflect in adaptation of modern demands of change as a result of the effects of historical processes on the social, cultural and physical environments.
\end{abstract}

Keywords: modernity, christianity, colonization

\section{INTRODUCTION}

Modern, modernity, modernization, modernism are the terms used spontaneously in describing a transformation of socio-historical process these days. Objectively, modernity is seen as a "process of modernization, by which the social world comes under the domination of asceticism, secularization, the universalistic claims of rationality and differentiation of various spheres of the lifeworld, bureaucratization of economic, political and military practices, and the growing monetarization of values" (Turner, 1990:6). As the basis of modernity consist of historical, cultural and social formations (Mee \& Kahn, 2012) and includes large areas of social process and cultural orientation comprised of globalization, transnationalism, nationalism, identity, the state, secularism capitalism, techno-rationality and religion.

From the colonial period to postcolonial era, Southeast Asia nation states have gone through dramatic historical developments and experienced political and economical changes. But looking at the history of popular music through the lense of the nation 
does not in itself produce the whole picture. Instead Barendregt (2014) proposes 'alternative conceptions of modernity' that problematize nation-centered narratives about the history of popular musics in Southeast Asia. Barendregt observes that modernity's production of new fashions, markets and lifestyles offers, “... a glimpse of how and why people have taken up ideas of the modern, how it is made, unmade and remade, paying ample attention to how such reconfigurations may serve various claims and are constantly haunted by yet others" (Barendregt, 2014:6). Those who are attached to how and why popular music is produced and created to meet the market demand attempt to fit into the current needs at that particular time period as well as create their own trends and developments within the society.

\section{Theoretical Framework/Discussion}

Recognizing the defiance of Western modernity, 'alternative conceptions of modernity' avoids nation-centered narratives and takes a holistic approach towards examining the multiple ways in which popular musics are attached to socio-culture developments in society. Some of the multiplicity of factors include issues of socio- economic and stages of socio-cultural development, educational development, Christianity, literacy, as well as stages of economic development in infrastructure, lifestyle and technology. All have been critical factors influencing definitions of modernity in the Iban society. The Iban in Sarawak have encountered various waves of modernization since the arrival of James Brooke in August 1839 where the history of Sarawak as a modern nation- state began (Kedit, 1980). Adapting to the new environment after the arrival of Western influence, the Brookes controlled, administered and maintained order to prepare the Iban to meet the needs and demands of a modern economy.

During the Brooke administration, influence from the Christian missionary and education had exposed the Iban to Western Music through hymn singing where they were exposed to Western melodic structures and harmony through the expectation of memorizing the hymns. Since 1950s, the Saribas Iban had listened to the radio on regular basis (Postill, 2006), the Iban established their contact to Western, Malay and Indonesian popular music played by the radio station. With radio providing a model, the Iban soon accelerated these innovations creating their own popular music, while expressing Ibaness through their own language, they adapted Western pop music melodies into their own early creations of pop music. Nevertheless, mimicking could also be seen as a reconfiguration in conveying their culture and expressions as social entertainment.

Looking as form of mass communication, popular music could serve as a mediator to communicate the 'desirability of modernity' as one of the ways to achieve rational development in the society (Hobart, 2006). As the modern infrastructure development is happening in the longhouse environment, the young girls are eager to follow the western entertainment, pop music, dancing the way the western people dress in the longhouse in order to be modern (Kedit, 1980). Consequently, as the desire of Iban to be modern, it had created a space in pop music creation and learning the music making process in innovating the Western, Malay and Indonesian music style into the newly created pop music. Hence, pop music had opened up the opportunity for 
the Iban to perform on stage and participating in singing competition had created the space among the community to explore their talent and skills in music.

\section{Case studies/Evidence/Empirical Data}

Popular music influences from Kuala Lumpur, Penang as well as Indonesia have been considerable throughtout the history the Iban popular music. These popular music styles have dictated from the centre to the 'periphery' where the Iban music industry is located in Sarawak. This "center-periphery" paradigm certainly describes the emergence of Iban popular music industry in Sarawak between 1954-1976, an era that gave rise to Iban radio broadcasting.

Radio Sarawak was officially established on the $8^{\text {th }}$ of June 1954, when the Sarawak Legislative Council decided to create a broadcasting service with technical assistance from the British Broadcasting Corporation (BBC). Among the four broadcast programs, including Malay, Iban, Chinese and English, the Iban programming was initially broadcast for just one hour from 7-8pm daily. In the early days, the programs were limited to news, information on agriculture and animal husbandry, Iban folklore, but also included sung poems (pantun, renong) and epics (ensera). In the 1950s, external musical influences from the Indonesian and Indian pop music dominated Iban airwaves and in the 1960s and 1970s, British and American popular music received substantial airplay. Radio Sarawak listeners enjoyed songs sung in Malay, Indonesian as well as English sung by British and American artist. Therefore, in order for an emerging Iban pop music industry to modernize, they composed songs using a popular form of their own language.

Both sisters, Senorita Linang and Pauline Linang were brought up listening to Western songs on the Sarawak Radio. Among their favourites were Tom Jones and Engelbert Humperdinck (Postill, 2006). Senorita Linang was an Iban beauty pageant winner and she was very much seen in the public eye as an icon of Ibanness. As an Iban singer cum artist, she was often perceived as a central icon to urban Iban audiences. She became the voice of Iban popular music in places where her songs reached her listeners in Sarawak through medium or shortwave frequency radio transmission. But she may also be considered as a periphery artist among the larger, more dominant Kuala Lumpur, Indonesian and Western artists promoted at the time. As a majority ethnicity of Sarawk, the Iban established themselves through the vehicle of popular music yet predictably remained a minority in larger urban centres.

In the 1970s, Christopher Kelly emerged in the Iban pop music industry after winning the RTM star competition (Pertandingan Bintang RTM). His first album entitled

'Beraie Nganti' was recorded in the 1970s and it received an overwhelming response from Iban music fans. He was crowned as the most popular lban artist in 1970s and the first Iban artist who had performed together with the RTM orchestra for National Day in year 1973. 'Bungai Layu', 'Nuan Meruan di Atiku', 'Agi Idup Agi Ngelaban', 'Tinggal Sari Asai Setaun', Beraie Nganti' are among the titles of Iban song which were popularized by him. In total, he had recorded 24 vinyl albums with RTM between 1970's to 1980 's and each vinyl disc contain 4 songs. Positioned on the periphery, the Iban 
artists did borrow tunes and rhythms from Western pop songs and adapted them as their own. But influences also included Malay and Hindustani genres that may be seen in Iban popular music. As Iban songs were broadcast on the radio station, the Iban popular music might have reached a wider audience from Indonesia, especially in Kalimantan region, Malaya through radio transmission.

But Iban radio programming has not always broadcast the sounds of modernity for its Iban listerners. In 1960s, the Sarawak government used Iban radio broadcasting for psychological warfare tactics against communist insurgents. During the end of the Indonesian confrontation in 1965, priorities of broadcast shifted from warfare propaganda to 'mental revolution of the people' with the aim to educate people with health and economic development information (Postill, 2006: 49). Christopher Kelly was especially brought to sing in the communist area of Sibu in the early 1970s, where the former whole Third Division of Sarawak (presently covering Sibu, Kapit, Sarikei and Mukah Divisions) was declared a special security area under the administration of Rajang Area Security Command (RASCOM) administered by the Chief Executive Officer whereas its Director of Operations is the Chief Minister of Sarawak. The places where Christopher Kelly was brought to perform as a singer cum entertainer included Pentas Rakyat (community stage show) in Nanga Ngungun operational area (Kanowit), Nanga Tada Operational area (Kanowit), Nanga Jagau operational area (Kanowit) and Nanga Sekuau operational area (Sibu) where he became the center figures of popular music.

During the communist movement of the 1960s, Iban soldiers were sent to Malaya. The song entitled 'Nganti Ti Pulai' was sung by Senorita Linang which means waiting for you to come back (Refer to Figure 1 for the Iban song lyrics and English translation). The melody of this song is taken from 'Sealed with a Kiss' in slow rock ballad sung by Brian Hyland, an American pop recording artist. The recording was released as a single in 1962. The Iban lyrics of the song portray the longing of a lover or fiancé towards a soldier. With separation as a theme, he had left her for a place far away, either for war or berjalai (literally means walking, acquiring new knowledge or wealth to be brought back to their village at the end of the journey). As depicted in the lyrics she misses him so much and prays he will be back soon. 
Don't go too long

I am left behind

Don't make me love sick

Please come back as possible, my love

To me that waiting for you

Don't go too long

Since you have been away

I feel so gloomy

It's hard to make myself happy

Hopping my gloominess will be stop

But it cannot be stopped,

Come back here soon

Every day I pray

Hope you will come back soon

All this long I have been waiting

For you, my love

Don't go too long

Come back soon

I wait everyday

For you to come back

To me that wait for you here

So that you come back soon

Every day I pray

Hope you will come back soon

All this long I have been waiting

For you, my love

For you to come back

To me that wait for you here

So that you come back soon

Figure 1: 'Nganti Ti Pulai' (Wait for you to come back) lyrics in Iban and the translation in English.

As seen in the lyrics (see Figure 2), the song evokes an Iban battle cry 'Agi Idup Agi Ngelaban' which means literally to fight to the death. It was composed during the 1960s and sung by Christopher Kelly during the government's era of urgent 'Malaysianisation'. It depicts the current scene of Sarawak joining Malaysia especially during the communist insurgency. Kelly's voice in the song urges the Iban soldiers to sacrifice all for their country. Because the song lyrics are in Iban, not Malaysian language, it creates a strong sense spirit of comradeship, a bond between Iban soldiers who fought bravely for their rapidly modernizing nation. The style of this song is very similar to 1960s pop melayu with Malay asli ornamentation in the melody. 


\begin{tabular}{|c|c|}
\hline $\begin{array}{l}\text { Diatu kitai udah Merdeka } \\
\text { Pegai perintah serakup Malaysia } \\
\text { Anang sekali bebagi ati } \\
\text { Ngetan ke menua sereta enggau negeri }\end{array}$ & $\begin{array}{l}\text { Now we are a free country here } \\
\text { Governed by formation of Malaysia } \\
\text { Don't be half hearted } \\
\text { Protect your country }\end{array}$ \\
\hline $\begin{array}{l}\text { Chorus: } \\
\text { Aram meh kitai ti nyadi sedadu Berambun ka } \\
\text { nyawa napi peluru Anang undur ngapa ari mena- } \\
\text { lan Enti agi idup agi ngelaban }\end{array}$ & $\begin{array}{l}\text { Come, those of us who are soldiers Sacrifice } \\
\text { your life against the bullet } \\
\text { Don't ever retreat from the war field } \\
\text { Fight until your last breath }\end{array}$ \\
\hline $\begin{array}{l}\text { Kitai meh bejuluk bujang berani } \\
\text { Ti tampak rita serta pegari }\end{array}$ & $\begin{array}{l}\text { We are the brave warriors } \\
\text { Who are famous and well known }\end{array}$ \\
\hline
\end{tabular}

Figure 2: 'Agi Idup Agi Ngelaban' (Fight until death) lyrics in Iban and the translation in English

Christian missionaries, formal education, as well as political and economic development dramatically changed the cultural and physical environment of the Iban as well as the Iban's perception towards their traditional culture. In addition, many Iban themselves were involved in internally discrediting their own culture. For example, traditional Iban belief systems were animistic and often involved shamans and ritual healers. As a reflection of modernization through migration to the urban, the song 'Cherita Manang Ula' (Story of 'Manang Ula') (See Figure 3) portrays the urban Iban's skeptical attitude towards the rural Iban traditional animism healing rituals. These were conducted by Iban shaman known as manang. Sung in the rhythm and melody is taken from Indonesian song with an exotic Hindustani flavor, this song depicts how a bogus shaman conducted a phony healing ritual.

Dinga kita cherita
Aki manang ula
Lebuh iya di ambi
Orang belian
Puchung sakarung
Di ma enggau baka
Endang siku orang
Di asoh iya ngesan
Leboh iya datai
Ba tudah ke sakit
Dia iya nanya
Nama pemedis
Tudah ke sakit
Pan madah diri
Kena hujan nyala
Pulai iya nginti

Listen to the story Shaman 'manang ula'

When he was invited

For healing ritual

Bundle of charms

In a basket he carried on his back

One men

Ask him to carry

When he arrive

At the place of the sick

Then he ask

What kind of sickness

The poor sick person

He tell about himself

Because of the 'hujan nyala'

When he comes back from fishing 
Manang ula lalu

Enda chamang-chamang

Mantai ka lupong

Batu pemandang

Dia iya lalu

Muchau besampi

Mandang ke batu

Segenap tisi

Batu iya kumbai

Iya batu ilau

Di kena nenggau

Ngabas penyakit

Udah nya baru

Iya mantai puchau

Di kena ngabau antu ti jai
Shaman 'manang ula', then,

Immediately

Take his basket

Batu pemantang (Crystal to see kind of sickness)

Then he start

Recite the speal

Looking at the crystal

In every angle

That crystal he called

As 'batu ilau' (crystal for seeing)

For him to see

Find out the sickness

After that,

He start recite the spell

For him to ward away the bad spirits

Figure 3: 'Cherita Manang Ula' (Story of 'Manang Ula') lyrics in Iban and the translation in English.

\section{SUMMARY}

This paper has addressed how 'alternative conceptions of modernity' have shaped and contributed to the musical development and socio-culture meaning of Iban pop music in Sarawak. Popular music in Iban society has endured influence from the hymns and Christian liturgy rendered into Iban language, English songs sung in mission schools, a mixture of Western, Malay and Indonesian pop songs and the diffusion of Western and Malay music into the Iban community. Since the beginning of radio station broadcasts, Iban popular music has been a strategic form of media towards nation building especially in the era of Malaysianisation when Sarawak joined Malaysia as a nation state.

A historical rupture between earlier modernities and the modernity we are presently dwelling, "This theory of a break-or rupture-with its strong emphasis on electronic mediation and mass migration, is necessarily a theory of the recent past (or the extended present) because it is only in the past two decades or so that media and migration have become so massively globalized, that is to say, active across large and irregular transnational terrains" (Appadurai, 1996:9). I agree with Appadurai because the Iban progressed remarkably over the few decades and massify themselves in the economic development process from the Brooke monarchy to Malaysia nation state. At the same time, the radio became a symbol of moderniy for the Iban who lives in the longhouse whereas the gramophone became the emblem of modernity for the urban Iban as crucial accessories to the development of new mass-mediated culture of consumption.

Due to the limited sources of music available to the Sarawak listeners at that time, the uniqueness of Iban pop is seen through the mixture of various genres of popular 
music ranging from Malay pop, Indonesian dangdut, Hindustani music, and Western ballads. It shows how these musical concepts blend together with the Iban language in the form of purely entertainment-based popular music. Although Iban pop music is not fully original composition, the pop music reflects the popular culture and lifestyle of Iban people especially how Iban people express their culture as well as their identity of Ibanness in the modernized environment.

\section{BIBLIOGRAPHY}

Appadurai, A. (1996). Here and Now. In Modernity at Large: Cultural Dimensions of Globalization (pp. 1-23). Minneapolis: University of Minnesota Press.

Barendregt, B. (2014). Sonic Histories in a Southeast Asian Context. In Sonic Modernities in the Malay World: A History of Popular Music, Social distinction and Novel Lifestyles (1930s-2000s) (pp. 1-43). Leiden: Brill.

Hobart, M. (2006). Introduction: why is entertainment television in Indonesia important?

Asia Journal of Communication, 16(4), 343-351.

http://doi.org/10.1080/01292980601012352

Kedit, P. M. (1980). Modernization among the Iban of Sarawak. Kuala Lumpur: Dewan Bahasa Dan Pustaka.

Mee, W., \& Kahn, J. S. (2012). Introduction. In W. Mee \& J. S. Kahn (Eds.), Questioning Modernity in Indonesia and Malaysia (pp. 1-17). Singapore: NUS Press in association with Kyoto University Press.

Postill, J. (2006). Media and Nation Building: How the Iban became Malaysia. New York, Oxford: Berghahn Books.

Turner, B. S. (1990). Periodization and Politics in the Postmodern. In Theories of Modernity and Postmodernity (pp. 1-13). London: Sage Publications Ltd. 